ISMC 2021

$16^{\text {th }}$ International Strategic Management Conference

\title{
IMPACT OF WORKPLACE ISOLATION ON JOB SATISFACTION OF AZERBAIJAN COMPANIES DURING COVID-19
}

\author{
Aygun Abdulova (a)* \\ *Corresponding author
}

(a) Ph.C. of UNEC, Azerbaijan, aygun_abdulova@unec.edu.az

\begin{abstract}
Coronavirus is a persistent and pandemic threat all over the world, and Azerbaijan is one of the countries that has been hit the worst by this new infection outbreak. Maintaining physical distance is recommended. Azerbaijan has undertaken policies intended at physical separation, including the closure of schools, institutions, and workplaces. Following the government of Azerbaijan's announcement of a state-wide curfew to prevent the spread of infection, some organizations throughout the country opted for distance working. During the Covid 19 outbreak in Azerbaijan, this empirical study seeks to evaluate how workplace isolation affects academic job satisfaction in private sector institutions. The researchers utilized a mixed-methods approach. A self-administered survey and semi-structured interviews were used to collect data. Using a suitable sample methodology, surveys were issued to 100 academics, and semistructured interviews were performed with 20 of them. Descriptive statistics and all correlation analyses even regression analysis, with thematic observation were used to analyze the data, followed by triangulation. Workplace isolation has a substantial negative association and impact on job satisfaction, according to the findings of the study. Furthermore, both physical and informational isolation have a detrimental influence on job satisfaction, with informational isolation having a greater influence than physical isolation. According to the study's findings, workplace isolation leads to lower job satisfaction in remote locations. Furthermore, the study concluded that employers must provide training options that include improved remote management to meet obstacles.
\end{abstract}

2357-1330 @ 2021 Published by European Publisher.

Keywords: Covid-19, Isolation from work, satisfaction from a job 


\section{Introduction}

Coronavirus is a persistent and pandemic threat all over the world and Azerbaijan is one of the countries that has been hit the worst by this new viral outbreak. Maintaining physical distance is recommended. Azerbaijan has undertaken policies geared towards physical separation, including the closure of schools, colleges, and workplaces. The first appearance of new coronavirus sickness in 2019 was discovered in December of this year, and it has since cleared all over the world, prompting global action. This has resulted in amazing efforts in the training of physical separation (called "social separating" at the time) in nations all over the world, resulting in revisions in national personal conduct norms and shutdowns of commonplace workplaces (Galea et al., 2002). The Azerbaijan government has stated that a statewide curfew will be implemented on Friday, March 20, 2020, at 18:00 (local time). It was lifted on the 11th of May 2020 after 52 days Following the government of Azerbaijan's announcement of a state-wide curfew on March 20, 2020, to prevent the spread of infection, some organizations across the country have opted for remote working. As a result, the airport, schools, universities, workplaces, and public gatherings have all been closed to comply with the government's policy. During pandemic all employees used team viewer, Zoom, Microsoft Teams, Google Meets, and Skype are some of the communication tools that are required for remote working, as well as task prioritizing and arrangements. When employees work remotely, they may feel alone at work (Marshall et al., 2007). Workplace isolation occurs when a distant worker feels neglected, which can hurt their performance and general Increase happiness, loneliness and lead to social and emotional deficits (Marshall et al., 2007).

The case within in work condition isolation was that when this happened, distant workers' performance on the job could suffer. However, a procedure conducted by (Bloom, N., Liang, et.al 2015) found that home-office applications, which are one of the most commonly utilized flexible working arrangements in enterprises, appeared to be enhancing individuals' work performance on all counts. They did, however, demonstrate that working from home raised feelings of loneliness and concerns about one's performance not being seen. Visibility is an important aspect in both job achievement and job enjoyment (Allen \& Griffeth, 2001).

Furthermore, several types of research on behavioral attitude have shown that greater technology confidence and, as a result, less efface contact may result in a reduction in job performance (Gibson \& Zellmer-Bruhn, 2001). Reduced job achievement, engagement, and identity, as well as increased work conditions social and physical confinement, have been observed in organizations with virtual environments where technology dependency is high and physical face-to-face contact is minimal (Mulki \& Jaramillo, 2011). During the epidemic, the Azerbaijan government declared a nationwide curfew on March 20, 2020, which was extended to a third phase till May 11, 2020. Because the majority of employees work from home, this is vital to keep the spread of infection to a minimum.

Because the Covid-19 Pandemic was first shared in December 2019, there isn't enough literature, evaluations, or articles on the impact of work condition isolation on job achievement. Literature is scarce about similar issues that aren't tied to Azerbaijan. 
As a result, the researcher decided to conduct this study on the impact of work condition confinement on employee job achievement during the Covid 19 pandemic to fill an experimental gap in the analyzed literature, with a focus on Azerbaijan private sector academics.

The current research focused on four main goals. They are to determine the current nature of workplace isolation and job satisfaction, to determine the relationship between workplace isolation and employee job satisfaction, to analyze the impact of workplace isolation on employee job satisfaction, and to determine how the characteristics of workplace isolation affect employee job satisfaction.

\section{Literature Review}

\subsection{Job satisfaction}

From several perspectives, the concept of occupational satisfaction is defined. "Job satisfaction is a person's amusement in his or her work life (Locke, 1976); employees' satisfaction in the work ambiance (Dawis \& Lofquist, 1984) a likable and amorous situation arising as a result of the evaluation of employees' job and experience (Testa, 1999); a likable and ardent direction arising as a result of the appraisal of employees' job and action (Testa, 1999).

In terms of organizations and employees, the importance of job happiness became apparent when a researcher seeking to increase organizational productivity focused on factors and human requirements rather than the structure and procedure of the company. Employees will be happier if their needs are met, and their motivation will rise.

To better understand job happiness, several theoretical and practical research has been done. Maslow's Hierarchy of Needs Theory, Herzberg's Two-Factor Theory, McClelland's Need for Achievement Theory, and Alderfer's ERG Theory are all important studies on job satisfaction (Brief, 1998).

Job satisfaction has been linked to (Hanisch \& Hulin, 1991) turnover intentions, absenteeism, firm citizenship, tiredness, physical and psychological well-being, the joy of life, productivity, leadership, personality, employee relationships, retirement age, and mobbing, according to studies.

\subsection{Workplace isolation}

From a developmental standpoint, solitude has heightened people's alertness, prompting them to seek out the company of others (Bowlby, 1973). Tribes recognized the importance of belonging to a group for survival and utilized physical and social seclusion to punish disobedient members.

Employees in today's firms believe that belonging to a group is crucial and that physical or social confinement is a source of difficulty and accent (House, 1981). This is because belonging to a group establishes acceptable behavior norms, reduces anxiety, improves performance, and allows workers to achieve goals that would have been difficult or impossible to achieve otherwise.

Furthermore, it is critical to briefly study the concept of loneliness and draw a distinction between it and occupational confinement. Loneliness is defined as the disagreeable practice that a person has when his or her social network is inadequate. 
According to previous studies on virtual work, virtual employees would face two types of confinement: social and organizational confinement. To begin with, these employees miss the social connection of unofficial chats, spontaneous discussions, and gatherings over the water cooler from a social standpoint (Cooper \& Kurland, 2002).

Second, implied employees fear being "out of sight and out of mind" for incentives on a corporate level (Bailey \& Kurland, 1999). They agree that their efforts are not accepted or valued (Cooper \& Kurland, 2002) and that their opportunities for advancement are limited compared to their traditional office colleagues (Bailey \& Kurland, 1999).

Implied office employees frequently believe that their bosses regard them as less committed to their jobs, as evidenced by their supervisors assigning them less visible projects, receiving minimal feedback, and providing less mentoring. Some virtual employees may believe that their bosses provide them less career advice in general (Pinsonneault \& Boisvert, 2001).

Workplace isolation and Job Satisfaction

Blending to the findings of there was a substantial and unfavorable relationship between aspects of workplace loneliness and job satisfaction. He also reveals that emotional deprivation and social interaction had a strong association with intrinsic satisfaction when they were combined.

Loneliness at work causes a misalignment of individual and organizational goals, lowers employee job satisfaction and capacity, and encourages fear of failure, feelings of ineptitude, disputed attitudes, work strain, a frightened corporate atmosphere, and perceived work stress.

\subsection{Conceptual Framework}

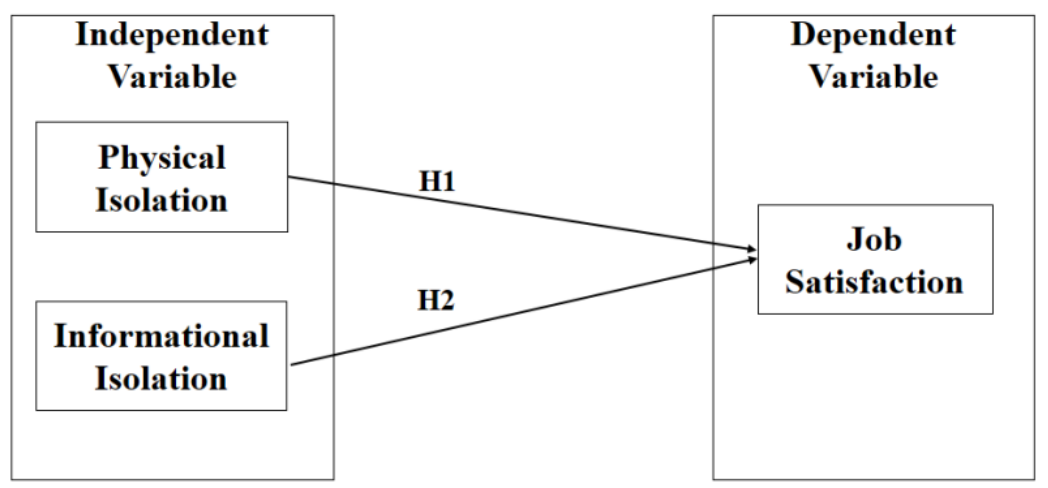

Figure 1. Conceptual Framework

H1: There is a connection between physical confinement and job happiness.

Physical depuration reduces interactions with others, reducing opportunities to form connections and increasing social isolation. Workers who work from home rarely have the convenience to interact with others. While earlier studies (Sims et al., 1976) did not find a direct link between job satisfaction and dealing with others and friendship opportunities, later studies (Levin \& Stokes, 1989) found that contact with others and friendship opportunities centrally influence job satisfaction. Hypothesis 1 will be tested.

$\mathrm{H} 2$ : There is a link between job happiness and informational isolation. 
According to organizational justice theories, the fair distribution of information among employees is just as crucial as the fair allocation of rewards. This also entails equal access to resources, such as information and crucial contacts. When employees do not have this chance, the meaning and joy they derive from their work will fade, and emotions of dissatisfaction may arise. To build on the findings of (Marshall et al., 2007). The second hypothesis will be checked.

\section{Research Methodology}

This study is based on secondary and primary data that was gathered through a Google Forms questionnaire survey distributed to employees of various enterprises in Azerbaijan companies. Based on Yamane's (1973) formula, a sample size of 353 was drawn from this group. Only 207 of the 353 surveys were found to be legitimate, representing a success rate of 56.5 percent. A total of 207 persons were included in the study, with 130 men and 77 women. For social science investigations, a sample size of 30 to 500 would be suitable and acceptable. The research is purely descriptive. It tries to figure out what elements influence work satisfaction in the IT business at the time of COVID-19. We may see results in the tables below (see table 1 and 2).

Table 1. Demographics of respondents

\begin{tabular}{ccc}
\hline Variable & Frequency & Percentage \\
\hline Male & 130 & $56.5 \%$ \\
Female & 77 & $43.5 \%$ \\
Transgender & 0 & $0.0 \%$ \\
Age in years (n=207) & Frequency & Percentage \\
More 26 years & 35 & $17.5 \%$ \\
$26-30$ & 58 & $27.0 \%$ \\
$31-35$ & 47 & $23.8 \%$ \\
Less 35 & 67 & 31.7 \\
\hline
\end{tabular}

Table 2. Analyzing of research

\begin{tabular}{|c|c|c|c|c|c|c|}
\hline & \multicolumn{3}{|c|}{ Kolmogorov-Smirnova } & \multicolumn{3}{|c|}{ Shapiro-Wilk } \\
\hline & Statistic & df & Sig. & Statistic & df & Sig. \\
\hline 1. Being able to keep busy all the time & .219 & 207 & .000 & .834 & 207 & .000 \\
\hline 2. The chance to work alone on the job & .281 & 207 & .000 & .834 & 207 & .000 \\
\hline $\begin{array}{l}\text { 3. The chance to do different things from } \\
\text { time to time }\end{array}$ & .395 & 207 & .000 & .732 & 207 & .000 \\
\hline $\begin{array}{l}\text { 4. The chance to be "somebody" in the } \\
\text { community. }\end{array}$ & .317 & 207 & .000 & .842 & 207 & .000 \\
\hline $\begin{array}{l}\text { 5. The way my boss handles his/her } \\
\text { workers. }\end{array}$ & .284 & 207 & .000 & .843 & 207 & .000 \\
\hline $\begin{array}{l}\text { 6. The competence of my supervisor in } \\
\text { making decisions. }\end{array}$ & .193 & 207 & .000 & .901 & 207 & .000 \\
\hline $\begin{array}{l}\text { 7. Being able to do things that don't go } \\
\text { against my conscience. }\end{array}$ & .325 & 207 & .000 & .817 & 207 & .000 \\
\hline $\begin{array}{l}\text { 8. The way my job provides for steady } \\
\text { employement. }\end{array}$ & .150 & 207 & .000 & .912 & 207 & .000 \\
\hline $\begin{array}{l}\text { 9. The chance to do things for other } \\
\text { people. }\end{array}$ & .314 & 207 & .000 & .827 & 207 & .000 \\
\hline
\end{tabular}




\begin{tabular}{|c|c|c|c|c|c|c|}
\hline 10. The chance to tell people what to do. & .337 & 207 & .000 & .826 & 207 & .000 \\
\hline $\begin{array}{l}\text { 11. The chance to do something that } \\
\text { makes use of my abilities. }\end{array}$ & .240 & 207 & .000 & .880 & 207 & .000 \\
\hline $\begin{array}{l}\text { 12. The way company policies are put into } \\
\text { practice. }\end{array}$ & .282 & 207 & .000 & .829 & 207 & .000 \\
\hline 13. My pay and the amount of work I do. & .280 & 207 & .000 & .856 & 207 & .000 \\
\hline $\begin{array}{l}\text { 14. The chances for advancement on this } \\
\text { job. }\end{array}$ & .175 & 207 & .000 & .906 & 207 & .000 \\
\hline $\begin{array}{l}\text { 15. The freedom to use my own } \\
\text { judgement. }\end{array}$ & .180 & 207 & .000 & .914 & 207 & .000 \\
\hline $\begin{array}{l}\text { 16. The chance to try my own methods of } \\
\text { doing the job. }\end{array}$ & .272 & 207 & .000 & .821 & 207 & .000 \\
\hline 17. The working conditions. & .293 & 207 & .000 & .792 & 207 & .000 \\
\hline $\begin{array}{l}\text { 18. The way my co-workers get along with } \\
\text { each other. }\end{array}$ & .284 & 207 & .000 & .817 & 207 & .000 \\
\hline 19. The praise I get for doing a good job. & .246 & 207 & .000 & .889 & 207 & .000 \\
\hline $\begin{array}{l}\text { 20. The feeling of accomplishment I get } \\
\text { from the job. }\end{array}$ & .255 & 207 & .000 & .887 & 207 & .000 \\
\hline
\end{tabular}

To understand the shape of the data's distribution and determine which type of test to apply for hypothesis testing and validation, the data were examined for normality. The data were subjected to two prominent tests in SPSS 25 version: the Kolmogorov-Smirnov test and the Shapiro-Wilk test. The results for both tests are shown in Table 3, and a visual inspection of the histograms, normal Q-Q plots, and box plots reveal that the work values scores are not normally distributed

\section{Conclusion}

At the time of COVID-19, the factors that had the most impact on job satisfaction in IT employees were "working conditions," "the opportunity to attempt my methods of doing the job," and "connection with coworkers." "Freedom to use my judgment" and "employment security" receive the lowest scores, possibly due to job insecurity emerging from COVID-19. IT Workers are given a higher score to outward fulfillment than natural fulfillment amid the current setting of COVID-19. There has been a noteworthy contrast within the job satisfaction of ITS workers about age, sexual orientation, and managerial/nonadministrative parts.

\section{References}

Allen, D. G., \& Griffeth, R. W. (2001). Test of a mediated performance-turnover relationship highlighting the moderating roles of visibility and reward contingency. Journal of applied psychology, 86(5), 1014. https://doi.org/10.1037/0021-9010.86.5.1014

Bailey, N., \& Kurland, N. B. (1999). The advantages and challenges of working here, there, anywhere, and anytime. Organizational Dynamics, 28(2), 53-68. https://doi.org/10.1016/S00902616(00)80016-9

Bloom, N., Liang, J., Roberts, J., \& Ying, Z. J. (2015). Does working from homework? Evidence from a Chinese experiment. The Quarterly Journal of Economics, 130(1), 165-218. https://doi.org/10.1093/qje/qju032

Bowlby, J. (1973). Attachment and loss: Volume II: Separation, anxiety and anger Attachment and Loss: Volume II: Separation, Anxiety, and Anger (pp. 1-429). The Hogarth press and the institute of psychoanalysis. 
Brief, A. P. (1998). Attitudes in and around organizations (Vol. 9): Sage

Cooper, C. D., \& Kurland, N. B. (2002). Telecommuting, professional isolation, and employee development in public and private organizations. Journal of Organizational Behavior: The International Journal of Industrial, Occupational and Organizational Psychology and Behavior, 23(4), 511-532. https://doi.org/10.1002/job.145

Dawis, R. V., \& Lofquist, L. H. (1984). A psychological theory of work adjustment: An individualdifferences model and its applications. University of Minnesota press.

Galea, S., Ahern, J., Resnick, H., Kilpatrick, D., Bucuvalas, M., Gold, J., \& Vlahov, D. (2002). Psychological sequelae of the September 11 terrorist attacks in New York City. New England journal of medicine, 346(13), 982-987. https://doi.org/10.1056/NEJMsa013404

Gibson, C. B., \& Zellmer-Bruhn, M. E. (2001). Metaphors and meaning: An intercultural analysis of the concept of teamwork. Administrative science quarterly, 46(2), 274-303. https://doi.org/10.2307/2667088

Hanisch, K. A., \& Hulin, C. L. (1991). General attitudes and organizational withdrawal: An evaluation of a causal model. Journal of vocational behavior, 39(1), 110-128. https://doi.org/10.1016/00018791(91)90006-8

House, J. S. (1981). Work stress and social support reading. Addison-Wesley.

Levin, I., \& Stokes, J. P. (1989). The dispositional approach to job satisfaction: Role of negative affectivity. Journal of applied psychology, 74(5), 752. https://doi.org/10.1037/0021-9010.74.5.752

Locke, E. A. (1976). The nature and causes of job satisfaction. In M. D. Dunnette (Ed.), Handbook of Industrial and Organizational Psychology (Vol. 1, pp. 1297-1343). Rand McNally College Publishing Company.

Marshall, G. W., Michaels, C. E., \& Mulki, J. P. (2007). Workplace Isolation: Exploring the Construct and Its Measurements. Psychology \& Marketing, 24(3), 195-223. https://doi.org/10.1002/mar.20158

Mulki, J. P., \& Jaramillo, F. (2011). Workplace isolation: salespeople and supervisors in the USA. The International Journal of Human Resource Management, 22, 902-923. https://doi.org/10.1080/09585192.2011.555133

Pinsonneault, A., \& Boisvert, M. (2001). The impacts of telecommuting on organizations and individuals: A review of the literature Telecommuting and virtual offices: Issues and opportunities (pp. 163185). IGI Global. https://doi.org/10.4018/978-1-878289-79-7.ch010

Sims, H. P. Jr, Szilagyi, A. D., \& Keller, R. T. (1976). The measurement of job characteristics. Academy of Management journal, 19(2), 195-212. https://doi.org/10.2307/255772

Testa, M. R. (1999). Satisfaction with organizational vision, job satisfaction and service efforts: an empirical investigation. Leadership \& Organization Development Journal, 20(3), 154-161. https://doi.org/10.1108/01437739910268424

Yamane, T. (1973). Statistics, An Introductory Analysis. Harper and Row. 